
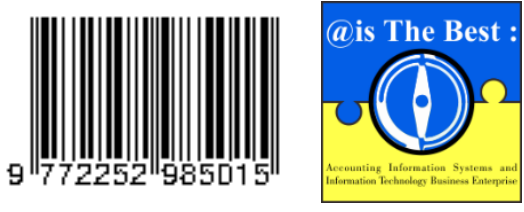

@is The Best :

Accounting Information Systems and

Information Technology Business Enterprise

Volume 03, Nomor 01

Juni 2018

P-ISSN: 2252-9853

E-ISSN:

DOI:

\title{
Perancangan Sistem Informasi Akuntansi Pajak Bumi Dan Bangunan (PBB) \\ Pada Kantor Kecamatan Cileunyi Bandung Dengan \\ Menggunakan Microsoft Visual Basic 6.0 Dan Microsoft SQL Server 2000 Berbasis Client Server
}

\author{
Jayinudin
}

BAHAGIya tailor Jln. Raya Bandung - Sumedang Desa. Hegarmanah 03/08

Kec. Jatinangor Kab. Sumedang 45363

Email: jayinudin@gmail.com

\section{Keywords:}

Design, Accounting

Information Systems,

Land and Building Tax,

Microsoft Visual Basic 6.0, SQL Server 2000

\section{Abstract}

Conditions that occur in the calculation of land tax and building in the Cileunyi District Office already using is based on Law No. 12 of 1994, but in performing procedures tax such as making tax monthly and annual reports are still using Microsoft Office Excel 2007. To the problems, then writer take the title: "Perancangan Sistem Informasi Akuntansi Pajak Bumi dan Bangunan (PBB) Pada Kantor Kecamatan Cileunyi Bandung Dengan Menggunakan Microsoft Visual Basic 6.0 Dan Microsoft SQL Server 2000 Berbasis Client Server".

The research used is basic research, the data used is qualitative data and quantitative data, the type of research design used is research design with primary data and secondary data, method of research used is exploratory research and descriptive, data collection techniques used is research field that consists of an interview and observation and research library.

\section{Abstrak}

Kondisi Perbitungan Pajak Bumi dan Bangunan di Kantor Kecamatan Cileunyi sudab berdasarkan Undang-Undang Nomor 12 Tabun 1994, namun dalam melakukan prosedur pajak seperti pembuatan laporan bulanan dan tabunan masib menggunakan Microsoft Office Excel 2007. Atas permasalaban tersebut maka penulis mengambil judul: "Perancangan Sistem Informasi Akuntansi Pajak Bumi dan Bangunan (PBB) Pada Kantor Kecamatan Cileunyi Bandung Dengan Menggunakan Microsoft Visual Basic 6.0 dan Microsoft SQL Server 2000 Berbasis Client Server".

Jenis penelitian yang digunakan adalah penelitian dasar, jenis data yang digunakan adalah data kualitatif dan kuantitatif, jenis desain penelitian yang digunakan adalah desain penelitian dengan data primer danvsekunder, metode penelitian yang digunakan adalah penelitian eksploratoris dan penelitian deskriptif, teknik pengumpulan data yang digunakan adalab penelitian lapangan yang terdiri dari wawancara dan observasi dan penelitian kepustakaan. 
Nama penulis : Jayinudin

Judul : Perancangan Sistem Informasi Akuntansi Pajak

Bumi dan Bangunan (PBB) Pada Kantor

Kecamatan Cileunyi Bandung dengan

Menggunakan Microsoft Visual Basic 6.0 dan

Microsoft SQL Server 2000 Berbasis Client Server
Jurnal @ is The Best

Vol. 02 No. 02. Desember 2017: Hal 288-300

\section{Pendahuluan}

Perkembangan Ilmu Pengetahuan dan Teknologi (IPTEK) semakin pesat mengikuti perubahan zaman, sehingga penggunaan komputer dalam kehidupan sehari-hari semakin meluas. Hal tersebut disebabkan karena komputer dapat membantu dan mempercepat suatu pekerjaan demi tercapainya kualitas informasi yang baik dan akurat, tepat waktu dan relevan.

Membayar pajak merupakan sebuah bentuk tanggung jawab warga negara dalam menjalankan kehidupan bernegaranya serta psjsk merupakan aset penting bagi negara dan merupakan salah satu faktor yang sangat penting untuk pembangunan sebuah negara. Sebagai contoh, Kantor Kecamatan yang bertugas melayani masyrakat wajib memungut biaya berupa pajak, khususnya pemungutan pajak bumi dan bangunan yang bertujuan untuk meningkatkan kesadaran masyrakat dalam membayar pajak bumi dan bangunan dan memudahkan masyrakat dalam proses pembayaran pajak bumi dan bangunan yang harus dikeluarkan atas kepemilikan bumi dan bangunan. Namun masih banyak dijumpai adanya tunggakan pajak sebagai akibat tidak dilunasinya hutang pajak sebagaimana mestinya.

Kantor Kecamatan Cileunyi adalah sebuah instansi pemerintah yang beralamat di Jl. Percobaan Cileunyi Bandung dalam proses pembuatan laporan bulanan dan tahunan untuk pajak bumi dan bangunan masih menggunakan Microsoft excel sehingga memungkinkan terjadinya kesalahan dalam memasukan data.

Berdasarkan uraian di atas, maka penulis tertarik untuk mengambil judul "Perancangan Sistem Informasi Akuntansi Pajak Bumi Dan Bangunan (PBB) Pada Kantor Kecamatan Cileunyi Bandung Dengan Menggunakan Microsoft Visual Basic 6.0 Dan Microsoft SQL Server 2000 Berbasis Client Server (Studi Kasus: Kantor Kecamatan Cileunyi)”

\section{Identifikasi Masalah}

Berdasarkan uraian di atas, penulis dapat mengambil identifikasi masalah sebagai berikut.

A. Bagaimana Sistem Informasi Pajak Bumi dan Bangunan (PBB) pada Kantor Kecamatan Cileunyi Bandung.

B. Bagaimana merancang Sistem Informasi Akuntansi Pajak Bumi dan Bangunan (PBB) pada Kantor Kecamatan Cileunyi Bandung dengan menggunakan software Microsoft Visual Basic 6.0 dan Microsoft SQL Server 2000.

\section{Batasan Masalah}

Berdasarkan uraian di atas, penulis membatasi masalah sebagai berikut ini.

A. Penulis membatasi hanya pada sub bag. keuangan dan pemungutan pajak bumi dan bangunan (PBB) hanya pada tingkat Kecamatan, yaitu pemungutan pajak wajib pajak (warga) yang tinggal dan mempunyai tanggungan atas pajak bumi dan bangunan di kecamatan Cileunyi, serta penyampaian SPT dilakukan oleh Kelurahan kepada Wajib Pajak (warga). 
Nama penulis : Jayinudin

Judul : Perancangan Sistem Informasi Akuntansi Pajak

Bumi dan Bangunan (PBB) Pada Kantor

Kecamatan Cileunyi Bandung dengan

Menggunakan Microsoft Visual Basic 6.0 dan

Microsoft SQL Server 2000 Berbasis Client Server
Jurnal @ is The Best

Vol. 02 No. 02. Desember 2017: Hal 288-300

B. Perancangan Sistem Informasi Akuntansi Pajak Bumi dan Bangunan (PBB) dengan menggunakan software Micrososft Visual Basic 6.0 dan menggunakan Microsoft SQL Server sebagai databasenya.

\section{Maksud dan Tujuan Penelitian}

Maksud dari penelitian tersebut adalah untuk memperoleh data yang berkaitan dengan Sistem Informasi Akuntansi Pajak Bumi dan Bangunan (PBB) dan merancang Sistem Informasi Akuntansi Pajak Bumi dan Bangunan (PBB) dengan software Micrososft Visual Basic 6.0 dan Microsoft SQL Server.

Adapun tujuan dari penelitian tersebut adalah sebagai berikut.

A. Untuk mengetahui Sistem Informasi Pajak Bumi dan Bangunan (PBB) pada Kantor Kecamatan Cileunyi Bandung.

B. Untuk merancang Sistem Informasi Akuntansi Pajak Bumi dan Bangunan (PBB) dengan menggunakan software Microsoft Visual Basic 6.0 dan Microsoft SQL Server.

\section{Kerangka Teoritis Dan Pengembangan Hipotesis}

\section{Perancangan}

Definisi perancangan dalam buku yang berjudul Sistem Informasi Manajemen Konsep dan Pengembangannya adalah sebagai berikut: "perancangan adalah spesifikasi umum dan terinci dari pemecahan masalah berbasis komputer yang telah dipilih selama tahap analisis"[1]. Sedangkan dalam buku yang berjudul Analisis dan Desain Sistem Informasi menyatakan bahwa: "perancangan adalah kemampuan untuk membuat beberapa alternatif pemecahan masalah”. [2]

Berdasarkan uraian di atas, penulis dapat menyimpulkan bahwa perancangan merupakan kemampuan untuk pemecahan sebuah masalah berbasis komputer.

\section{Sistem}

Definisi sistem dalam buku yang berjudul Analisis dan Desain adalah sebagai berikut: "sistem adalah suatu jaringan kerja dari prosedur-prosedur yang saling berhubungan, berkumpul bersama-sama untuk melakukan sesuatu kegiatan untuk menyelesaikan suatu kegiatan atau untuk menyelesaikan suatu sasaran tertentu" [3]. Sedangkan dalam buku yang berjudul Sistem Akuntansi, "sistem adalah suatu jaringan prosedur yang dibuat menurut pola yang terpadu untuk melakukan kegiatan pokok perusahaan" [4].

Berdasarkan uraian di atas, penulis dapat menyimpulkan bahwa sistem merupakan kumpulan beberapa jaringan yang berhubungan satu sama lain untuk menyelesaikan suatu sasaran tertentu.

\section{Informasi}

Definisi informasi dalam buku yang berjudul Analisis dan Desain adalah sebagai berikut: "informasi adalah data yang diolah menjadi bentuk yang lebih berguna dan lebih berarti bagi yang menerimanya" [3]. Sedangkan dalam buku Memahami Sistem Informasi menjelaskan bahwa: 
Nama penulis : Jayinudin

Judul : Perancangan Sistem Informasi Akuntansi Pajak

Bumi dan Bangunan (PBB) Pada Kantor

Kecamatan Cileunyi Bandung dengan

Menggunakan Microsoft Visual Basic 6.0 dan

Microsoft SQL Server 2000 Berbasis Client Server
Jurnal @ is The Best

Vol. 02 No. 02. Desember 2017: Hal 288-300

“informasi adalah rangkaian data yang mempunyai sifat sementara, tergantung dengan waktu, mampu memberi kejutan atau surprise pada yang menerimanya" [5].

Berdasarkan uraian di atas, penulis dapat menyimpulkan bahwa informasi merupakan rangkaian data yang telah diolah dan memberi manfaat bagi penerima.

\section{Sistem Informasi}

Definisi sistem informasi dalam bukunya yang berjudul Analisis dan Desain menjelaskan bahwa:

"Sistem Informasi adalah suatu sistem di dalam suatu organisasi yang mempertemukan kebutuhan pengolahan transaksi harian, mendukung operasi, bersifat manajerial dan kegiatan strategi dari suatu organisasi dan menyediakan pihak luar tertentu dengan laporan-laporan yang diperlukan.” [3].

Sedangkan dalam buku yang berjudul Memahami Sistem Informasi menjelaskan bahwa: "sistem informasi adalah sistem yang berisi SPD (Sistem Pengolahan Data) yang dilengkapi dengan kanal-kanal komunikasi yang digunakan dalam sistem organisasi data" [5]

Berdasarkan uraian di atas, penulis dapat menyimpulkan bahwa sistem informasi merupakan suatu sistem pengolah data dalam suatu organisasi yang bersifat manajerial.

\section{Akuntansi}

Definisi akuntansi menurut buku yang berjudul Akuntansi Suatu Pengantar menyebutkan bahwa: "akuntansi adalah proses mengidentifikasikan, mengukur dan melaporkan informasi ekonomi, untuk memungkinkan adanya penilaian dan keputusan yang jelas dan tegas bagi mereka yang menggunakan informasi tersebut."[6]

\section{Sistem Informasi Akuntansi}

Definisi sistem informasi dalam buku yang berjudul Sistem Informasi Manajemen adalah sebagai berikut: "sistem informasi akuntansi adalah kumpulan dari subsistem-subsistem yang saling berhubungan satu sama lain dan bekerja sama secara harmonis untuk mengolah data keuangan menjadi informasi keuangan" [1]

Sedangkan dalam buku yang berjudul Analisis dan Desain Sistem Informasi, "sistem informasi akuntansi adalah kumpulan kegiatan dari organisasi yang bertanggung jawab untuk menyediakan informasi keuangan dan informasi yang didapat dari transaksi data untuk tujuan pelaporan internal kepada manajer." [3].

Berdasarkan uraian di atas, penulis menyimpulkan bahwa sistem informasi akuntansi merupakan kumpulan subsistem atau kegiatan organisasi yang saling berhubungan yang dapat mengolah data transaksi menjadi informasi keuangan.

\section{Pajak Bumi dan Bangunan (PBB)}

Berdasarkan buku yang berjudul Perpajakan menyebutkan bahwa: "pajak bumi dan bangunan adalah pajak yang dikenakan terhadap bumi dan bangunan”. [7]. 
Nama penulis : Jayinudin

Judul : Perancangan Sistem Informasi Akuntansi Pajak

Bumi dan Bangunan (PBB) Pada Kantor

Kecamatan Cileunyi Bandung dengan

Menggunakan Microsoft Visual Basic 6.0 dan

Microsoft SQL Server 2000 Berbasis Client Server
Jurnal @ is The Best

Vol. 02 No. 02. Desember 2017: Hal 288-300

Berdasarkan uraian di atas, penulis menyimpulkan bahwa Pajak Bumi dan Bangunan (PBB) merupakan iuran rakyat atas kekayaan bumi dan bangunan yang dimiliki.

\section{Sistem Informasi Akuntansi Pajak Bumi dan Bangunan}

Berdasarkan beberapa uraian di atas, maka dapat disimpulkan bahwa sistem informasi akuntansi Pajak Bumi dan Bangunan (PBB) merupakan suatu sistem yang dapat mengolah data menjadi sebuah informasi dengan cara mengidentifikasi, mengukur dan melaporkan informasi Pajak Bumi dan Bangunan (PBB) oleh seseorang atau badan hokum dan melaporkan sekaligus menyetorkan ke kas Negara.

\section{Perancangan Sistem Informasi Akuntansi Pajak Bumi dan Bangunan}

Berdasarkan uraian di atas, penulis dapat menyimpulkan bahwa perancangan sistem informasi akuntansi Pajak Bumi dan Bangunan (PBB) merupakan sebuah kemampuan alternatif untuk memecahkan suatu masalah dalam pengolahan data dari iuran Pajak Bumi dan Bangunan menjadi sebuah informasi keuangan yang dapat memberi manfaat bagi organisasi atau perusahaan.

\section{Metode}

\section{Unit Analisis}

Berdasarkan buku yang berjudul Metodologi Penelitian Untuk Bisnis, menjelaskan bahwa: "unit analisis adalah tingkat pengumpulan data yang dikumpulkan selama analisis data" [8] Sedangkan berdasarkan Kamus Besar Indonesia, "unit analisis ialah penyelidikan terhadap suatu peristiwa untuk mengetahui keadaan yang sebenarnya" [9].

Berdasarkan definisi diatas, unit analisis yang dilakukan adalah penelitian yang berhubungan dengan Pajak Bumi dan Bangunan pada Kantor Kecamatan Cileunyi Jl. Percobaan Cileunyi Bandung.

\section{Populasi dan Sampel}

Dalam buku yang berjudul Metode Penelitian, "populasi adalah kumpulan dari individu dengan kualitas serta ciri-ciri yang telah ditetapkan. Sampel adalah bagian dari populasi”..[10]

Berdasarkan uraian di atas, maka populasi yang diambil adalah laporan bulanan untuk Pajak Bumi dan Bangunan (PBB) tahun 1991-2009 yang ada di Kantor Kecamatan Cileunyi Jl. Percobaan Cileunyi Bandung.

Sedangkan sampel yang diambil adalah laporan bulanan untuk Pajak Bumi dan Bangunan (PBB) tahun 2008 dan 2009 yang ada di Kantor Kecamatan Cileunyi Jl. Percobaan Cileunyi Bandung.

\section{Objek Penelitian}

Penulis melakukan penelitian pada Bagian Akuntansi yaitu pada Sistem Informasi Akuntansi Pajak Bumi dan Bangunan (PBB) yang ada di Kantor Kecamatan Cileunyi Jl. Percobaan Cileunyi Bandung.

\section{Desain Penelitian}


Nama penulis : Jayinudin

Jurnal @ is The Best

Judul : Perancangan Sistem Informasi Akuntansi Pajak

Bumi dan Bangunan (PBB) Pada Kantor

Kecamatan Cileunyi Bandung dengan

Menggunakan Microsoft Visual Basic 6.0 dan

Microsoft SQL Server 2000 Berbasis Client Server

Vol. 02 No. 02. Desember 2017: Hal 288-300

Desain penelitian dalam buku yang berjudul Metode Penelitian, "desain dari penelitian adalah semua proses yang diperlukan dalam perencanaan dan pelaksanaan penelitian. Pengertian lebih sempit, desain penelitian hanya mengenai pengumpulan dan analisis data saja."[10]

Dalam hal ini, penulis menggunakan desain penelitian data primer dan sekunder, karena penulis memperoleh data langsung dari pihak pertama dengan cara wawancara dan memperoleh data berupa dokumen.

\section{Metode Penelitian}

Metode penelitian yang dilakukan untuk mengetahui fakta-fakta tentang peristiwa yang terjadi di lapangan adalah penelitian eksploratoris, penelitian deskriptif dan penelitian survei.

\section{Teknik Pengumpulan Data}

Teknik pengumpulan data yang dilakukan penulis adalah sebagai berikut.

A. Penelitian Lapangan (field Research)

1) Wawancara (Interview)

2) Pengamatan (Observation)

3) Penelitian Pustaka (Library Research)

\section{Metodologi Pengembangan Sistem}

Metodologi pengembangan dalam buku yang berjudul Analisis Sistem Informasi terbagi ke dalam tiga bagian, yaitu:

"A. Metodologi yang Berorientasi Pada Proses

B. Metodologi yang Berorientasi Pada Data

C. Metodologi yang Berorientasi Pada Outpué' [7]

\section{Struktur Pengembangan Sistem}

Struktur pengembangan sistem yang digunakan adalah waterfall.

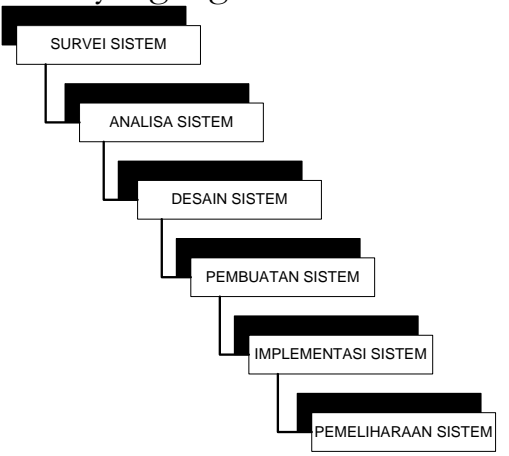

Gambar 1 Struktur Pengembangan Sistem [7]

\section{Lokasi Penelitian}

Penulis melakukan penelitian pada bagian Sub Bag. Keuangan di Kantor Kecamatan Cileunyi Bandung Jl. Percobaan Cileunyi Bandung. 
Nama penulis : Jayinudin

Jurnal @ is The Best

Judul

: Perancangan Sistem Informasi Akuntansi Pajak

Bumi dan Bangunan (PBB) Pada Kantor

Kecamatan Cileunyi Bandung dengan

Menggunakan Microsoft Visual Basic 6.0 dan

Microsoft SQL Server 2000 Berbasis Client Server

Vol. 02 No. 02. Desember 2017: Hal 288-300

\section{Hasil dan Pembahasan}

\section{Dokumen dan Catatan Usulan}

A. Bukti pembayaran pajak

B. Surat pemberitahuan objek pajak (SPOP),

C. surat pemberitahuan pajak terutang (SPPT)

D. surat tagihan pajak (STP).

E. Jurnal Umum

F. Buku Besar Umum

G. Laporan Pendapatan

\section{Data Flow Diagram yang Diusulkan}

a. Diagram Konteks yang Diusulkan

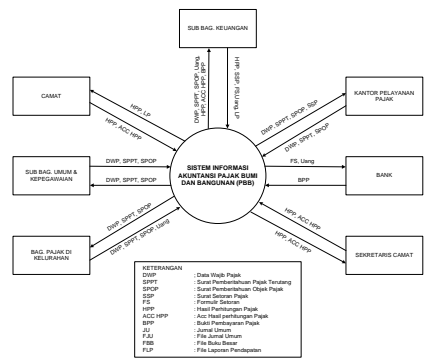

Gambar 2 Diagram Konteks yang Diusulkan

b. Diagram Level 0 yang Diusulkan

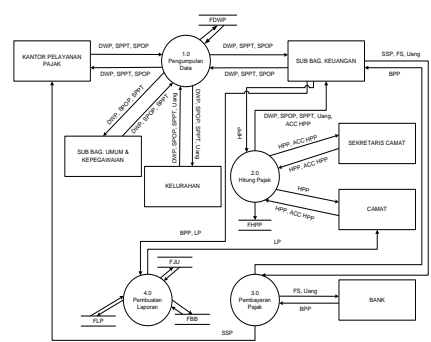

Gambar 3 Diagram Level 0 yang Diusulkan

c. Bagan Alir yang Diusulkan

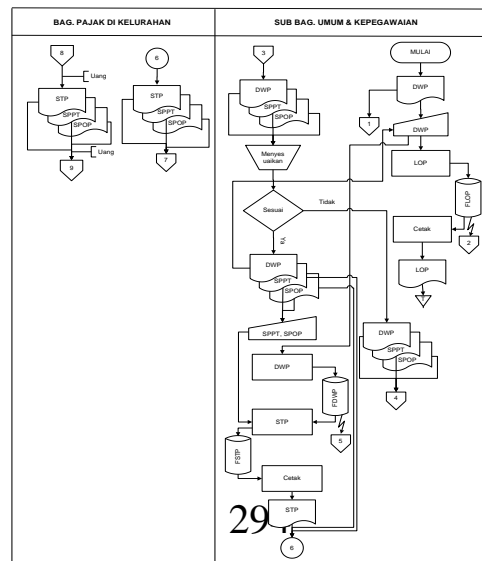


Nama penulis : Jayinudin

Jurnal @ is The Best

Judul : Perancangan Sistem Informasi Akuntansi Pajak

Bumi dan Bangunan (PBB) Pada Kantor

Kecamatan Cileunyi Bandung dengan

Menggunakan Microsoft Visual Basic 6.0 dan

Microsoft SQL Server 2000 Berbasis Client Server

Vol. 02 No. 02. Desember 2017: Hal 288-300

Gambar 4 Bagan Alir yang Diusulkan

d. Entity Relationship Diagram yang Diusulkan
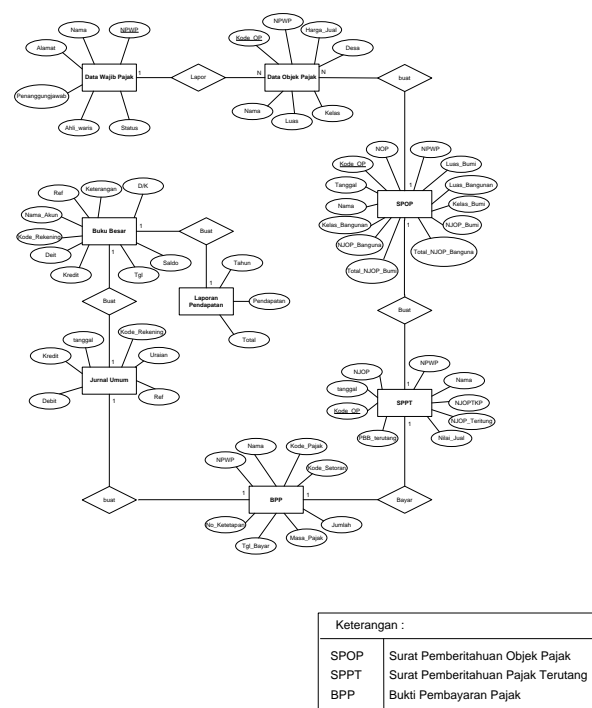

Gambar 5 Entity Relationship Diagram yang Diusulkan

\section{e. Tampilan Menu Program}

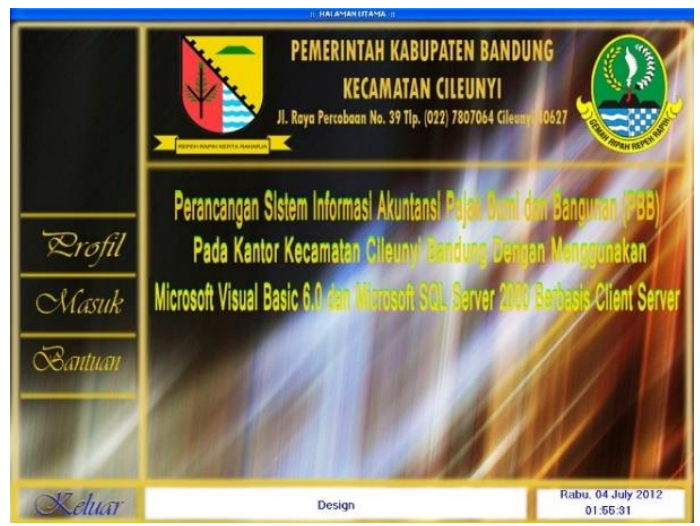

Gambar 6 Tampilan Halaman Utama

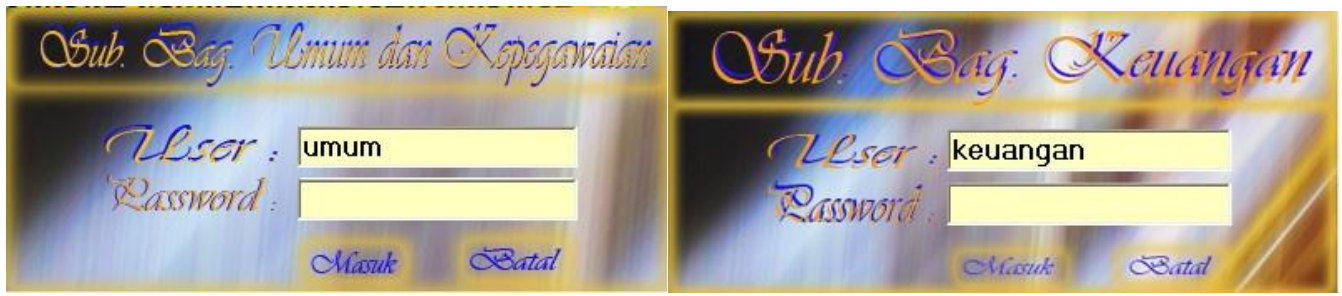

Gambar 7 Tampilan Menu Masuk 
Nama penulis : Jayinudin

Jurnal @ is The Best Judul

: Perancangan Sistem Informasi Akuntansi Pajak

Bumi dan Bangunan (PBB) Pada Kantor

Kecamatan Cileunyi Bandung dengan

Menggunakan Microsoft Visual Basic 6.0 dan

Microsoft SQL Server 2000 Berbasis Client Server

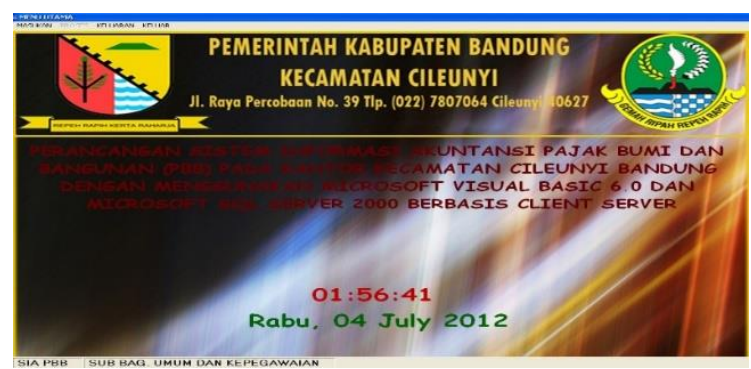

Gambar 8 Tampilan Menu Utama Sub Bag. Umum dan Kepegawaian

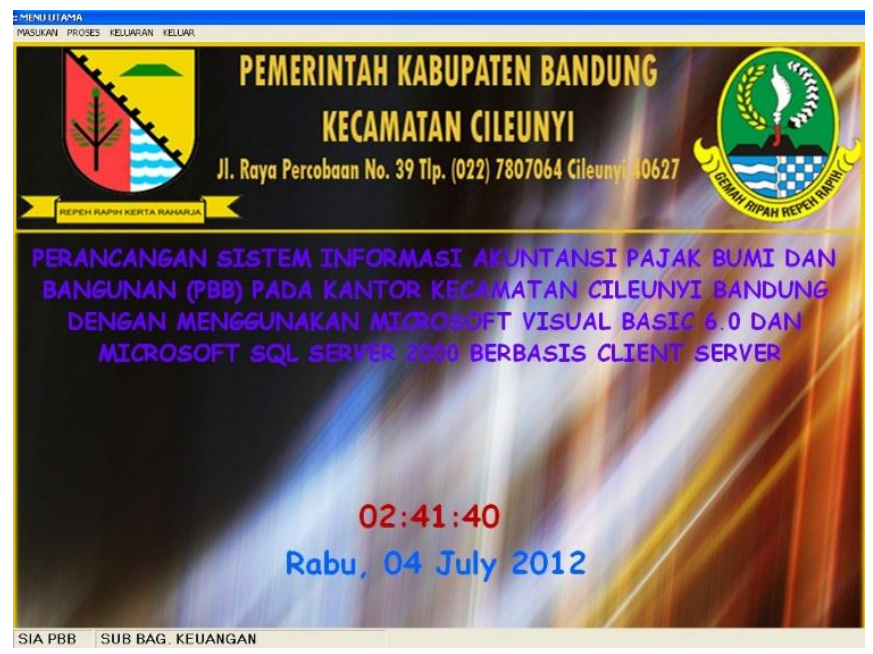

Gambar 9 Tampilan Menu Umum Sub Bag. Keuangan

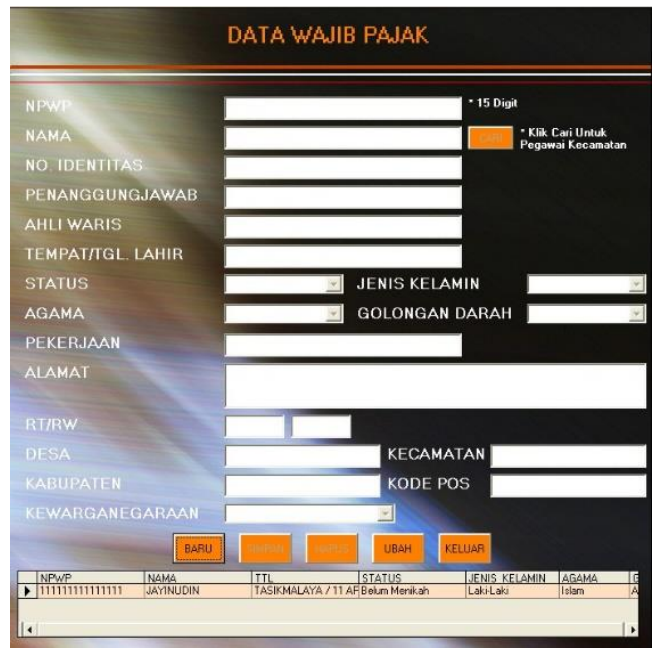


Nama penulis : Jayinudin

Judul

: Perancangan Sistem Informasi Akuntansi Pajak

Bumi dan Bangunan (PBB) Pada Kantor

Kecamatan Cileunyi Bandung dengan

Menggunakan Microsoft Visual Basic 6.0 dan

Microsoft SQL Server 2000 Berbasis Client Server
Jurnal @ is The Best

Vol. 02 No. 02. Desember 2017: Hal 288-300

Gambar 10 Tampilan Data Wajib Pajak

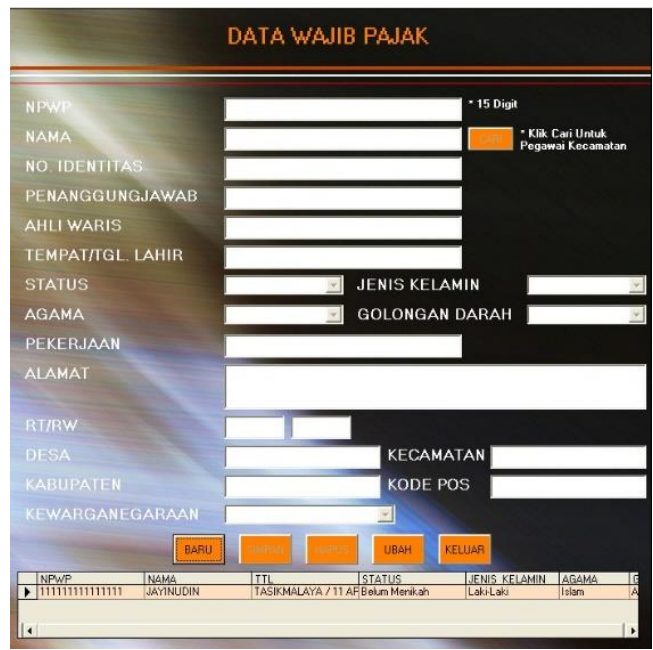

Gambar 11 Tampilan Data Pegawai

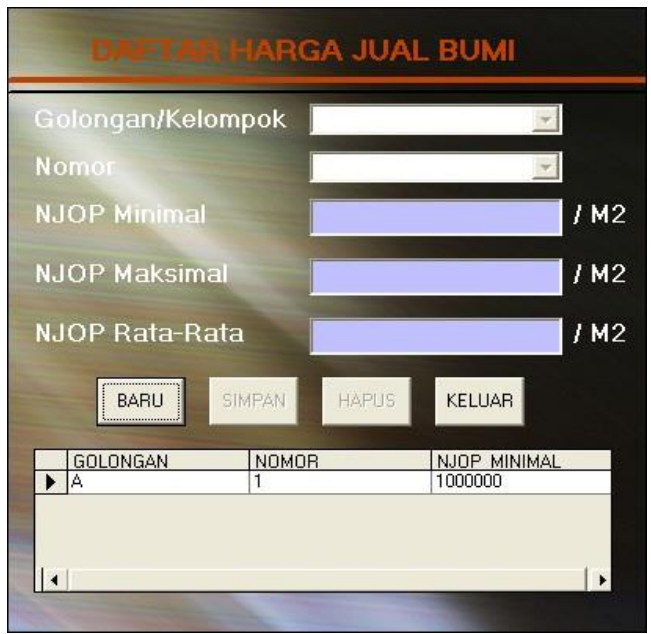

Gambar 12 Tampilan Daftar Harga Jual Bumi 
Nama penulis : Jayinudin

Jurnal @ is The Best

Judul

: Perancangan Sistem Informasi Akuntansi Pajak

Bumi dan Bangunan (PBB) Pada Kantor

Kecamatan Cileunyi Bandung dengan

Menggunakan Microsoft Visual Basic 6.0 dan

Microsoft SQL Server 2000 Berbasis Client Server

Vol. 02 No. 02. Desember 2017: Hal 288-300

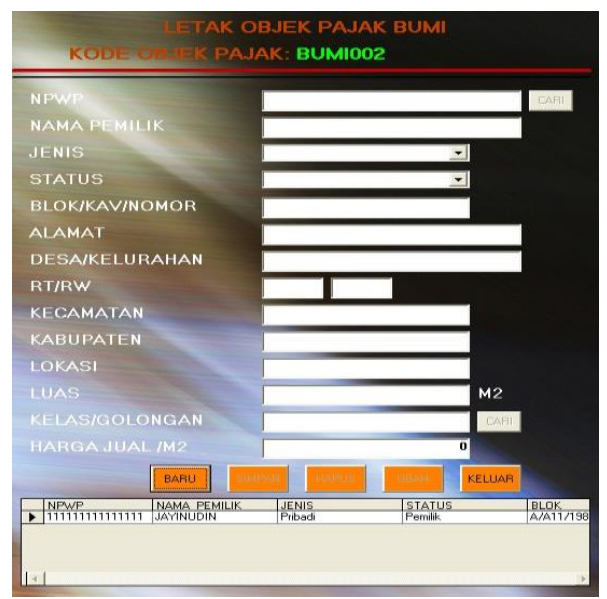

Gambar 13 Tampilan Letak Objek Pajak Bumi

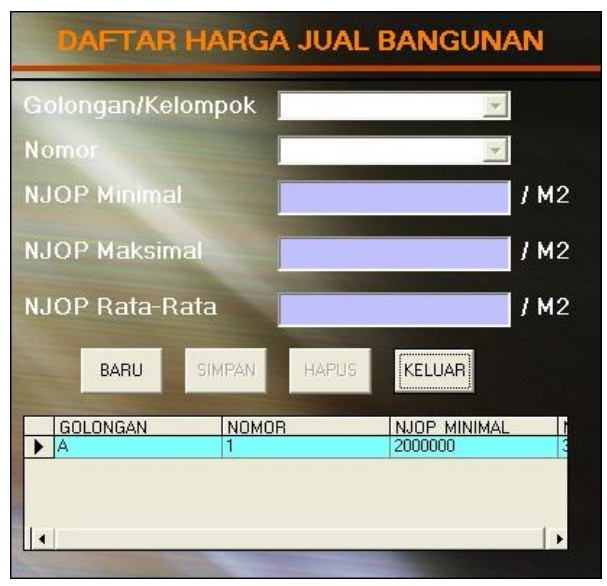

Gambar 14 Tampilan Daftar Harga Jual Bangunan 
Nama penulis : Jayinudin

Jurnal @ is The Best

Judul

: Perancangan Sistem Informasi Akuntansi Pajak

Bumi dan Bangunan (PBB) Pada Kantor

Kecamatan Cileunyi Bandung dengan

Menggunakan Microsoft Visual Basic 6.0 dan

Microsoft SQL Server 2000 Berbasis Client Server

Vol. 02 No. 02. Desember 2017: Hal 288-300

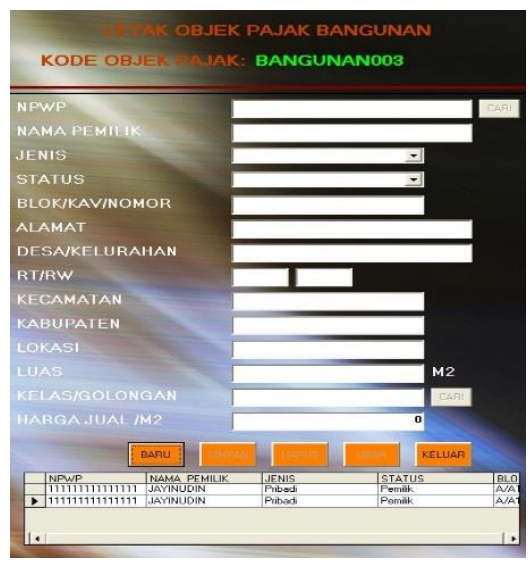

Gambar 15 Tampilan Letak Objek Pajak Bangunan

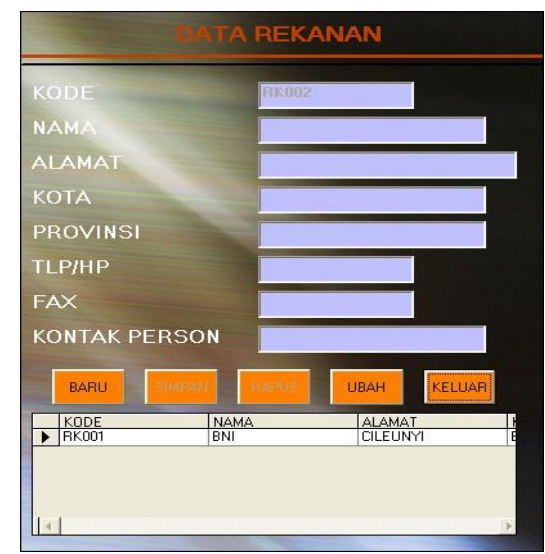

Gambar 16 Tampilan Data Rekaman 
Nama penulis : Jayinudin

Judul : Perancangan Sistem Informasi Akuntansi Pajak

Bumi dan Bangunan (PBB) Pada Kantor

Kecamatan Cileunyi Bandung dengan

Menggunakan Microsoft Visual Basic 6.0 dan

Microsoft SQL Server 2000 Berbasis Client Server
Jurnal @ is The Best

Vol. 02 No. 02. Desember 2017: Hal 288-300

\section{Penutup}

\section{Simpulan}

Kantor Kecamatan Cileunyi Bandung pada pencatatan laporan keuangan dan perpajakannya masih menggunakan sistem manual, yaitu Microsoft Excel. Maka kemungkinan akan terus mengalami kesalahan dalam pencatatannya. Oleh karena itu, dibutuhkan suatu sistem informasi akuntansi pajak bumi dan bangunan. Penulis menggunakan Microsoft visual basic 6.0 dan Microsoft SQL Server 2000 serta berbasis client server dalam pembuatannya.

\section{Saran}

A. Perlu diadakan pengembangan sistem informasi akuntansi berbasis komputer yang dapat mengelola dan mengolah data lebih cepat, tepat, dan akurat.

B. Instansi disarankan menggunakan program aplikasi pajak bumi dan bangunan yang dibuat, maka komputer yang digunakan minimal mengguanakan Processor AMD Athlon, INTEL Pentium 4, Motherboard K7SOM+, Motherboard INTEL, Harddisk Minimal $20 \mathrm{~Gb}$, memory DDR $512 \mathrm{MB}$ dan terdapat Software windows XP, Microsoft Visual Basic 6.0 dan SQL Server 2000.

\section{Daftar Pustaka}

[1] A. Susanto, Sistem Informasi Manajemen Konsep dan pengembangannya. Bandung: Lingga Jaya, 2004.

[2] L. Bin and Al-Bahra, Analisis dan Desain Sistem Informasi. Yogyakarta: Graha Ilmu, 2005.

[3] Jogiyanto, Analisis dan Desain Informasi. Yogyakarta: ANDI, 2005.

[4] Mulyadi, Sistem Akuntansi. Jakarta: Salemba Empat, 2001.

[5] Witarto, Memahami Sistem Informasi. Jakarta: Salemba Empat, 2004.

[6] Soemarso, Akuntansi Suatu Pengantar. Jakarta: Salemba Empat, 2002.

[7] T. Sutarbi, Analisa Sistem Informasi. Yogyakarta: ANDI, 2004.

[8] U. Sekaran, Metodologi Penelitian untuk Bisnis. Jakarta: Salemba Empat, 2006.

[9] T. P. K. P. Bahasa, Kamus Besar bahasa Indonesia. 2001.

[10] M. Nazir, Metode Penelitian. Jakarta: Ghalia Indonesia, 2005. 